\title{
HELMINTHIASIS IN CAPTIVE WILD CARNIVORES AND ITS CONTROL IN INDIA
}

\author{
L.N. Acharjyo
}

House No. M-71, Housing Board Colony, Baramunda, Bhubaneshwar, Orissa 751003, India

\begin{abstract}
Helminthiasis in wild carnivores can cause high morbidity and mortality specially in young ones. This paper discusses in brief on the occurrence of helminthic infestation in wild carnivores as reported from India. They suffer from trematodes, cestodes, nematodes and acanthocephala infestation. Paragonimiasis, hydatidosis, dinofilariasis, hookworm infection and toxocariasis appear to be common among these animals. The various helminths recorded from Indian wild carnivores along with the host animal and location of the parasite have been listed. Infestation with trematodes, cestodes and nematodes have been frequently reported but there appears to be only one report of acanthocephala infestation from a Jungle Cat. The paper also discusses about the principles of control measures for helminthiasis in wild carnivores that can be adopted in Indian zoos.
\end{abstract}

\section{KEYWORDS}

Acanthocephala, captive wild carnivores, cestodes, control measures, Indian zoos, helminthiasis, nematodes, recommendations, review, trematodes

Many species of carnivores specially felids, canids, hyenas, bears, civets, mongooses, otters and red panda are usually exhibited in most of the Indian zoos. The major concern to managers and veterinarians of zoos is the health aspects of these wonderful creatures. There are scores of health problems arising out of various aetiological agents. However, parasitic infestations - especially those with helminthic origin affecting wild carnivores would be presently the subject of discussion. Since parasitism and its control in free-living wild carnivores is more complex and difficult to achieve due to obvious reasons, it would be prudent to limit the topic to captive wild carnivores of the Indian zoos. Therefore, it is necessary to know about the occurrence of different helminth parasites in captive wild carnivores before attempting any control measure.

Helminthic infestations have greater ramification and significant impact in these animals, when present in sufficient number and can cause high morbidity and mortality. These may be expressed as deaths in all age groups especially in young ones and weakness and unthriftness in survivors who may as a result have lowered body resistance and reproduction capabilities. Additionally poor exhibition value of animals in captivity and zoonotic risks to zoo employees could be the other facets of parasitic infestations.

\section{Trematodes}

Paragonimiasis: It is a parasitic infection of zoonotic importance of both free living and captive wild carnivores.

The disease is widely distributed throughout the country and has been reported in Tiger (Panthera tigris), Leopard (Panthera pardus), Clouded Leopard (Neofelis nebulosa), Rusty-spotted
Cat (Prionailurus rubiginosus), Leopard Cat (Prionailurus bengalensis), Fishing Cat (Prionailurus viverrinus), Golden Cat (Catopuma temmincki), Jungle Cat (Felis chaus), Palm Civet (Paradoxurus grayi), Small Indian Civet (Viverricula indica), Large Indian Civet (Viverra zibetha), Himalayan Pine Marten (Mustela martis), Bear-cat (Arctictis binturong) and Common Mongoose (Herpestes edwardsi) (Mudaliar \& Alwar, 1947; Hiregoudar \& Pethkar, 1970; Singh \& Somvanshi, 1978; Dutt \& Gupta, 1978; Arora \& Das, 1988; Parihar \& Shrivastava, 1988; Rao \& Acharjyo, 1991; Rao et al., 1991; Pythal et al., 1993; Arora, 1994; Arora et al., 1998; Varadharajan \& Pythal, 1999; Chowdhury, 2001; Nashiruddullah \& Chakraborty, 2001).

The most common species encountered in Indian wild carnivores is Paragonimus westermanii though $P$. compactus, $P$. edwardsi and $P$. kellicotti have also been reported from few wild hosts.

The flukes remain inside the cysts chiefly in the lung parenchyma and rarely in brain, spinal cord and other organs without causing serious damage. Consequently, the death due to paragonimiasis is rather extremely rare. Most of the diagnosis of reported cases are based on post-mortem findings and in few instances through faecal sample examination.

The other important trematodes of wild carnivores reported from India by Patnaik and Acharjyo (1970), Amrithraj et al. (1999) and Chowdhury (2001) are listed in Table 1.

\section{Cestodes}

Echinococcosis/hydatidosis: Echinococcus granulosus, the causative parasite has wide geographical distribution and lives in the small intestine of carnivores (particularly the dog) and the metacestode (hydatid cyst) in various organs of a wide variety of ungulates and man (Soulsby, 1986). Because of its potentiality to affect man, the parasite is considered to be of zoonotic consequence.

There are reports on the occurrence of hydatid cysts in the liver of lions of old Madras Zoo (Ramanujachari \& Alwar, 1954) and Maharajbagh Zoo, Nagpur (Ganorkar et al., 1997).

Echinococcus granulosus worms associated with marked catarrhal enteritis were recovered from both small and large intestines of an Indian Wolf (Canis lupus) during necropsy at Nandankanan Zoo (Rao et al., 1973).

The other cestodes / metacestodes reported from Indian wild carnivores (from small intestines) are given (Mudaliar \& Alwar, 1947; Patnaik \& Acharjyo, 1970; Arora, 1994; Chowdhury, 2001; Nashiruddullah \& Chakraborty, 2001) in Table 2. 
Table 1. The important trematodes of wild carnivores reported from India

\begin{tabular}{lll}
\hline Name of the parasite & Name of the host & Location \\
\hline Artyfechinostomum malayanum & Small Indian Civet & Intestine \\
Artyfechinostomum sufrartyfex & Honey Badger / Palm Civet & Small Intestine \\
Echinochasmus corvus & Jackal & Intestine \\
Echinochasmus perfoliatus & Rusty Spotted Cat & Small Intestine \\
Euparadistomum sundarami & Mongoose & Gall bladder \\
Euparyphium malayanum & Jungle Cat & Intestine \\
Haplorchis taichui & Fox & Small intestine \\
Pharyngostomum cordatum & Tiger / Jungle Cat & Small Intestine \\
Spelotrema narii & Jackal & Small Intestine \\
\hline
\end{tabular}

\section{Nematodes}

Dirofilariasis: Dirofilariasis or heartworm disease, caused by Dirofilaria immitis is a vector-borne disease having zoonotic importance.

Dirofilaria immitis is usually found in right ventricle of heart, pulmonary artery, vena cava and occasionally in lungs when the infestation is heavy. The disease has been reported from a wide range of wild felids and canids, namely, Lion (Panthera leo), Leopard and Black Panther (Panthera pardus), Tiger and White Tiger (Panthera tigris), Golden Cat (Catopuma temmincki), Jackal (Canis aureus), Fox (Vulpes bengalensis), Wild Dog (Cuon alpinus) and Wolf (Canis lupus) at Nandankanan Zoo (Rao \& Acharjyo, 1993); Asiatic Lion (Panthera leo persica) at Guwahati Zoo (Nashiruddullah \& Chakraborty, 2001); and Lioness (Panthera leo) at Ranchi Zoo (Haque, 1998). Heartworms were detected in all these species only during necropsy.

Dirofilaria repens was found in the subcutaneous tissue of Indian Fox (Vulpes bengalensis) and Golden Cat (Catopuma temmincki) at Nandankanan Zoo (personal observation \& A.T. Rao, pers. comm.).

Lungworm infection: Rao et al. (1971) recovered Filaroides osleri from nodules in the lungs of a Leopard Cat (Prionailurus bengalensis) suffering from pneunomia at Nandankanan Zoo.

Hookworm infection: Hookworms occur in a wide range of hosts and are cosmopolitan in distribution. The parasites cause haemorrhagic and necrotic enteritis resulting in loss of blood and anaemia. Most of the carnivores specially the felids and canids exhibited in Indian zoos harbour various species of hookworms. One of the species, Galonchus perniciosus causing nodular disease of the intestines has been frequently encountered in Lion, Tiger and Leopard at Nandankanan Zoo during post-mortem examination. Nashiruddin and Chakraborty (2001) recorded G. perniciosus in Indian Tiger from Assam State Zoo and studied the pathology in detail. Pythal et al. (1993) have also reported $G$. perniciosus infection in a Leopard.

Hookworm infection has also been recorded from different species of wild carnivores from India like Wild Dog, Wolf, Jackal, Fox, Jungle Cat, Leopard Cat, Clouded Leopard, Hyena, Lion, Tiger, Civet Cat, Honey Badger, Fishing Cat, Leopard,
Table 2. The other cestodes / metacestodes reported from Indian wild carnivores from small intestines

\begin{tabular}{ll}
\hline Cestode/metacestode & Wild carnivore host \\
\hline Dipylidium caninum & Indian Fox, Hyena, Jackal \\
Dipylidium otocyonis & Fox \\
Diphyllobothrium caninum & Hyena \\
Diphyllobothrium erinaceae & Tiger \\
Diphyllobothrium felis & Tiger \\
Diphyllobothrium latum & Leopard, Leopard Cat, Tiger, Wild Cat, Jackal \\
Mesocestoides lineatus & Leopard, Indian Fox, Jackal \\
Multiceps multiceps & Jackal \\
Spirometra erinaceae & Tiger, African Lion, Clouded Leopard, Fishing \\
& Cat, Jungle Cat, Small Indian Civet \\
Taenia hydatigena & (sparganum in the sub-cutaneous tissue). \\
Taenia pisiformis & Jackal, Tiger \\
Taenia taeniaeformis & Tiger, Jackal, Jungle Cat \\
\hline
\end{tabular}

Sloth Bear, Mongoose and Red Panda. The list of hookworm species reported (Chowdhury, 2001) are given as under. These worms were recovered from small intestine only: Ancylostoma caninum, A. braziliense, A. ceylanicum, A. duodenale, A. paraduodenale, Anthrocephalus gambiensis, A. herpestis, Uncinaria felidis, U. stenocephala .

Rao and Acharjyo (1972) recovered several number of Anthrocephalus longespiculum from a fibromatous growth in the pancreas of a Hog Badger (Arctonyx collaris). Chakraborty and Chowdhary (1985) recorded Acheilostoma collaris, a new species from the pancreas of a Hog Badger.

Toxocariasis: Toxocariasis is very common in carnivores specially felids causing ill health in all the age groups and mortality in young ones. Chakraborty and Maity (1995) reported the death of five $1 \frac{1}{2}$ month old Himalayan Wolf pups at Darjeeling Zoo due to the above malady caused by Toxocara canis. Successful treatment of clinical cases of toxocariasis in Snow Leopards caused by Toxocara cati has been reported from Darjeeling Zoo (Maity et al., 1994). An Asiatic Lion of Bikaner Zoo which suffered from parasitic gastritis caused by Toxocara leonina was successfully treated (Tanwar et al., 1984). A survey of faecal samples of wild mammals of Kanpur Zoo revealed the presence of Toxocara leonina in both African and Indian lions, Tiger and Fishing Cat. Ascaris felis was noticed in Indian Lion in Nandankanan Zoo. The recovery of T. leonina from Asiatic Lion and Tiger; T. cati from Leopard and Jungle Cat and T. canis from Tiger and Jackal at Assam State Zoo have been recorded (Nashiruddullah \& Chakraborty, 2001). Toxocara mystax from Tiger, Leopard, Jungle Cat and Leopard Cat and T. transfuga from Himalayan Black Bear, Sloth Bear and Red Panda have also been reported (Chowdhury, 2001). Besides, few other species of nematodes reported in Indian wild carnivores Chowdhury (2001) and Nashiruddullah and Chakraborty (2001) have been listed in Table 3.

Acanthocephala: There appears to be only one report on the occurrence of Oncicola sp. from Jungle Cat in Nandankanan Zoo (Patnaik \& Acharjyo, 1970) 
Table 3. Other nematodes reported by Chowdhury (2001) and Nashiruddullah and Chakraborty (2001) in Indian wild carnivores

\begin{tabular}{|c|c|c|}
\hline Parasite & Host & Location \\
\hline Belascaris marginata & Jackal, wolf, fox & Intestine \\
\hline $\begin{array}{l}\text { Bronchostrongylus } \\
\text { subcrenatus }\end{array}$ & Tiger & Bronchi and trachea \\
\hline Capillaria aerophila & Tiger & Bronchi and trachea \\
\hline Capillaria cameroni & Jungle cat & Urinary bladder \\
\hline Capillaria sp. & Leopard-cat & Kidney \\
\hline Capillaria sp. & Mongoose & Intestine \\
\hline Cyclospirura subequalis & Tiger, jungle cat & Cysts in stomach wall \\
\hline Dracunculus medinensis & Leopard, Jackal & Sub-cutaneous tissue \\
\hline Gnathostoma spinigerum & $\begin{array}{l}\text { Leopard, tiger, jackal, } \\
\text { civet cat, golden cat }\end{array}$ & $\begin{array}{l}\text { Stomach, liver, body } \\
\text { cavity, mesentery, } \\
\text { diaphragm etc. }\end{array}$ \\
\hline Herpestrongylus herpesti & Mongoose & $\begin{array}{l}\text { Body cavity, lungs, } \\
\text { gall bladder }\end{array}$ \\
\hline Metathelazia cameroni & Jungle Cat & Lung \\
\hline Metathelazia chabaudi & Mongoose & Bronchioles \\
\hline Ollulanus tricuspis & Lion, Tiger & Stomach \\
\hline Parascaris felis & Lion & Intestine \\
\hline Physaloptera brevispiculum & Jungle Cat, Honey badger & Stomach \\
\hline Physaloptera masoodi & Jungle Cat & Stomach \\
\hline Physaloptera preputualis & $\begin{array}{l}\text { Clouded Leopard, Leopard, } \\
\text { Fishing Cat, Jungle Cat, } \\
\text { Leopard Cat }\end{array}$ & Stomach \\
\hline Physaloptera vulpineus & Fox & Stomach \\
\hline Physaloptera sp. & Tiger, Fox, Mongoose & Stomach \\
\hline Viverra nisakimolensis & Civet Cat, Jungle Cat & Intestine \\
\hline Spirocerca lupi & $\begin{array}{l}\text { Jungle Cat, Bear Cat, } \\
\text { Lion, Jackal }\end{array}$ & $\begin{array}{l}\text { Mainly oesophogus } \\
\text { and stomach }\end{array}$ \\
\hline Spirura herpestis & Mongoose & Stomach \\
\hline Spirura ritypleurites & Mongoose & Stomach \\
\hline Strongyloides akbari & Honey badger & Intestine \\
\hline Strongyloides tumefaciens & Jungle Cat & Large Intestine \\
\hline Subulura vulpes & Fox & Intestine \\
\hline Vogdeloides herpesti & Mongoose & Bronchioles \\
\hline Toxocara canis & Jackal, Lion, Leopard, Tiger & Small intestine \\
\hline Toxocara cati & $\begin{array}{l}\text { Lion, Tiger, Leopard, } \\
\text { Clouded Leopard, Fishing } \\
\text { Cat, Leopard Cat, Jungle } \\
\text { Cat, Golden Cat, Civet }\end{array}$ & Intestine \\
\hline Toxocara leonina & $\begin{array}{l}\text { Lion, Tiger, Leopard, Snow } \\
\text { Leopard, Fox, Fishing Cat, } \\
\text { Leopard Cat }\end{array}$ & Small Intestine \\
\hline Rictularia mjobergi & Bear Cat & Intestine \\
\hline Rictularia cahirensis & Civet Cat, Honey Badger & Intestine \\
\hline Rictularia affinis & Jackal & Intestine \\
\hline Rictularia sp. & Small Indian Civet & Stomach \\
\hline Trichinella spiralis & Civet Cat & $\begin{array}{l}\text { Diaphragm, skeletal } \\
\text { muscles }\end{array}$ \\
\hline Trichuris sp. & Tiger, Mongoose & $\begin{array}{l}\text { Caecum, Large } \\
\text { Intestine }\end{array}$ \\
\hline
\end{tabular}

\section{Principles of control measures}

Though helminth parasites are known to occur in free-living wild carnivores, there appears to be no specific information on the pattern of morbidity and mortality.

The diverse geoclimatic conditions of India presents a panorama of helminthic infestations among wild carnivores peculiar to each region. The control measures, undoubtedly, would depend upon several factors like life cycle, preponderance of intermediate hosts, survivability of the non-infective stage of parasites in nature, availability of susceptible hosts, status of nutrition, season and environment. For example, the eggs of some of the helminths like ascarids remain viable for several months and the life cycle of several helminths involve intermediate hosts (e.g. snail and crab or crayfish (Paragonimus sp.), mosquitoes
(Dirofilaria immitis), rodents as paratonic hosts (Toxocara $\mathrm{sp.)}$ etc.). The degree of parasitaemia may also be influenced by housing, zoo sanitary measures, periodic deworming etc. Therefore, it is desirable to have a proper understanding of the design and dimension of animal enclosure, micro- and macroclimate of the enclosure environment, species, population size, sex and age group of carnivores maintained, feeding and management practices, life cycle and epidemiology of helminths involved, susceptibility and concurrent disease etc. Further, the rationale behind the control of helminths in wild carnivores of Indian zoos is presumptive in as much as each carnivore is infected and that the contamination of the zoo environment is a continuous process because of space confinement, over crowding, movement of keepers from one enclosure to the other, presence of stray dogs, cats, rodents, mosquitoes etc.

All the above relevant issues will have a definite bearing on control measures designed to be adopted for a particular species in a zoo. Some of the measures which may be adopted in Indian zoos are described below.

1. Newly arrived carnivores should be kept in quarantine at least for a period of 30 days as they can be a potential source of helminthic infection to the resident healthy zoo carnivores. During quarantine, frequent screening for helminths followed by treatment of positive cases with appropriate anthelmintic should be carried out.

2. It is generally believed that nutritional deficiency increases the susceptibility of animals to helminthic infection. Therefore, adequate supply of good quality, hygienic and nutritious diet as per the need of the species and clean water from protected source must be ensured.

3. The feeding/retreating housing facilities must have impervious and crack-free surfaces both on the floor and walls to facilitate proper cleaning and disinfection. Houses must be well illuminated and ventilated.

4. Good drainage system to prevent water logging, dampness and unhygienic condition must be ensured. The enclosure environment should be kept clean and dry.

5. Periodical drive to eliminate/ prevent the spread of mosquitoes, flies, snails, rodents, stray dogs, cats etc. inside the zoo premises should be carried out as they serve as vectors/ transmitters of helminthic infection.

6. The excreta and food refuses of carnivores and all sorts of garbage, solid and liquid wastes generated inside the zoo premises can act as reservoir and breeding ground for diseasecausing helminths and their vectors. Therefore, proper cleaning and disposal of wastes daily and disinfection with desired disinfectants of the enclosure and surrounding areas is a must.

7. General zoo sanitary measures of animal enclosures and surrounding areas including the veterinary complex and all places frequented by visitors must be ensured. Hospital wastes should 
be properly disinfected and disposed off.

8. It is most unlikely to keep wild carnivores absolutely free from helminthic infestation. Hence a monitoring-and-controlof-helminths programme should be implemented with an aim to reduce the parasitic burden. This can be achieved by periodical faecal sample examination for three consecutive days and treatment of positive cases with appropriate broad spectrum anthelmintic on a regular basis. The deworming schedule usually adopted for wild carnivores in most of the Indian zoos should be strictly followed.

9. Change of anthelmintics should be instituted from time to time to avoid drug resistance.

10. There is seasonal variation in helminthic infection among all animals including wild carnivores. Special emphasis has to be given during rainy season followed by winter and summer seasons.

11. Young animals are more vulnerable to helminthic infection. As such they warrant special attention and care at birth and thereafter.

12. Since stress of all kinds increases the susceptibility to parasitic infection, attempts should be made to avoid stress as far as possible in the daily routines.

13. When helminthiasis is persistent, the host animalenvironment relation has to be considered. Heavy build up of infective parasitic fauna may be present in the top soil of the enclosure creating an environment for repeated infection. In such cases periodic changing of the infected top soil of the ground may help in the control of helminths to a great extent.

14. Overcrowding of enclosures must be avoided as otherwise frequent reinfection may occur.

\section{REFERENCES}

Amirthraj, M., B. Michael and K.M. Pillai (1999). Artyfechinostomum malayanum (Leiper, 1911) Mendheim, 1943 from a small Indian civet (Viverricula indica). Zoos' Print Journal 14(4): 6.

Arora, B.M. (1994). Wildlife Diseases in India. Periodical Expert Book Agency, New Delhi.

Arora, B.M. and Das, S.C. (1988). Helminth infestation in a tigress (Panthera tigris) Indian Journal of Veterinary Medicine 8(2): 154-156.

Arora, B.M., A. Prasad and N.S. Parihar (1998). Paragonimiasis in Panthera pardus. Wildlife Information Bulletin 4(1): 10.

Chakraborty, A. and B.N. Choudhury (1985). Pathology of the pancreas of a Hog Badger caused by Acheilostoma collaris, pp.64-65. Proceeding of the workshop on wildlife health for veterinarians, 22-25 April, Dehradun.

Chakraborty, T. and B. Maity (1995). Toxocariasis in Himalayan wolf (Canis lupus chanco) pups. Indian Journal of Veterinary Pathology 19(2): 136.

Chowdhury, N. (2001). Indian Subcontinent, pp. 287-368. In: Chowdhury, N. and A.A. Aguirre (Eds.). Helminths of Wildlife. Science Publishers, Inc. Enfield.

Dutt, S.C. and P.P. Gupta (1978). Paragonimiasis in bear-cat (Arctictis binturong). Annals of Tropical Medical Parasitology 72(4): 391-393. Ganorkar, A.G., S.W. Kolte and N.V. Kurkure (1997). Occurrence of hydatid cysts in a lion. Indian Journal of Veterinary Pathology 21: 64.
Gaur, S.N.S., M.S. Seethi, H.C. Tewari and O. Prakash (1979). A note on the prevalence of helminth parasites in wild and zoo animals in Uttar Pradesh. Indian Journal of Animal Science 49(2): 159-161.

Haque, S. (1998). Heart worm in a lioness - a case report, pp.53-54. Abstracts of the Proceedings of National Symposium on Health Care Practices for Livestock Productivity in 21 ${ }^{\text {st }}$ Century, 21-23 January 1998. Dr. Panjabrao Deshmukh Krishi Vidyapeeth, Akola.

Hiregoudar, L.S. and D.K. Pethkar (1970). Paragonimus westermanii from a Clouded Leopard in India. Gujvet 4: 84-86.

Maity, B., G. Chakraborty and K.K. Pradhan (1994). Toxocariasis in Snow Leopard (Panthera uncia). Indian Veterinary Journal 71(5): 499-501.

Mudaliar, S.V. and V.S. Alwar (1947). A checklist of parasites (classes of Trematoda and Cestoda) in the Department of Parasitology. Madras Veterinary College Laboratory. Indian Veterinary Journal 71(5): 499-501. Nashiruddullah, N. and A. Chakraborty (2001). Parasites of captive wild carnivores of Assam State Zoo. Intas Polivet 2(11): 173-181.

Parihar, N.S. and S.N. Shrivastava (1988). Bronchial hyperplasia in a tiger (Panthera tigris). Indian Journal of Animal Science 58(2): 230-233. Patnaik, M.M. and L.N. Acharjyo (1970). Notes on the helminth parasites of vertebrates in Baranga zoo (Orissa). Indian Veterinary Journal 47(9): 723-730.

Pythal, C., K.M. Pillai, C.G. Varghese and T. Surenderanathan (1993). Death of a Wild Indian leopard Panthera pardus fusca (Meyer) due to parasitism with the lung fluke. Paragonimus westermanii (Kerbert, 1878) and the hookworm Galonchus perniciosus (Linstow, 1885). Kerala Journal of Veterinary and Animal Science 24: 44-46.

Ramanujachari, G. and V.S. Alwar (1954). A checklist of parasites (Classes - Trematoda, Cestoda and Nematoda) in the Department of Parasitology, Madras Veterinary College. Indian Veterinary Journal 31: 46-56.

Rao, A.T. and L.N. Acharjyo (1972). Histopathology of the parasitic nodule associated with Anthrocephalus longespiculum, Maplestone, 1931 (Syn: Uncinaria philippinensis, Chitwood, 1932, Uncinaria logespicula, Sandground, 1933) in the pancreas of a Hog Badger (Arctonyx collaris). Current Science 41(16): 614-615.

Rao, A.T. and L.N. Acharjyo (1993). Incidence of heart worms in captive wild carnivores. Indian Journal of Parasitology 17(2): 201-202.

Rao, A.T., L.N. Acharjyo and B.B. Bhatia (1971). A note on the histopathology of lungs of a leopard cat (Felis bengalensis) due to Filaroides osleri (Cobbold, 1879) Skrjabin, 1933. Indian Journal of Animal Science 41: 844-846

Rao, K.N.P., A.C. Bandopadhyaya and B.G. Mandalekar (1991). Paragonimiasis in a tiger. Zoos Print 6(5): 16.

Rao, A.T., B.C. Nayak and L.N. Acharjyo (1973). Histopathology of intestinal lesions due to Echinococcus granulosus in an Indian Wolf (Canis lupus). Indian Veterinary Journal 50(2): 199-200.

Singh, N.P. and R. Somvanshi (1978). Paragonimus westermanii in tigers (Panthera tigris). Journal of Wildlife Diseases 14: 322-324.

Soulsby, E.J.L. (1986). Helminthis, Arthropods and Protozoa of Domesticated Animals. English Language Book Society / Bailliere Tindall, Eastbourne.

Tanwar, R.K., L.M. Mittal, S.N. Sharma and J.S. Yadhav (1984). Parasitic gastritis in an Asian Lion - a case report. Indian Journal of Veterinary Medicine 4(1): 48-49.

Varadharajan, A. and C. Pythal (1999). A preliminary investigation on the parasites of wild animals at the zoological garden, Thiruvananthapuram, Kerala. Zoos' Print Journal 14: 159-164. 